\title{
DISKURSUS FATWA ULAMA TENTANG PERAYAAN NATAL
}

\author{
Abdul Manan \\ Fakultas Adab dan Humaniora UIN Ar-Raniry \\ Jl. Ar-Raniry Darussalam, Banda Aceh, 23111 \\ e-mail: mananaceh@yahoo.com
}

\begin{abstract}
Abstrak: Artikel ini bertujuan untuk mendiskusikan secara kritis tentang pendapat ulama mengenai ucapan selamat natal. Fatwa-fatwa tentang natal dikeluarkan sebagai dampak dari perdebatan tentang kehadiran seorang Muslim pada perayaan-perayaan natal. Sebagian ulama meyakini bahwa perayaan natal dapat menjadi godaan kuat bagi umat Islam untuk ikutserta dalam perayaan tersebut. Ulama ini mengajukan temuan bahwa para ulama mempunyai pandangan berbeda tentang ajaran Islam mengenai mengucapkan selamat natal kepada orang-orang Kristen. Kelompok pertama meyakini bahwa mengucapkan selamat natal kepada orang Kristen tidak diperbolehkan, sedangkan kelompok kedua meyakini bahwa orang-orang Islam diperbolehkan untuk menghadiri dan mengucapkan selamat natal kepada mereka. Secara historis, dunia Muslim telah memberikan respons terhadap eksistensi dan ritual perayaan natal dengan cara merayakan hari kelahiran Nabi (maulid Nabi) dan sebagian ulama hendak membuktikan perayaan natal bidah bagi Muslim.
\end{abstract}

\begin{abstract}
The Fatwa of Ulama Council Discourse on Christmas Celebration. This article aims to discuss critically about mufti opinion on Christmas celebration salutation. The opinions about Christmas were issued as a result of the debate about the presence of Muslim in Christmas celebration. Some muftis believe that Christmas can be a strong temptation for Muslims to participate in its celebrations. The muftis submit a finding that every mufti has different perception about Islam on saying congratulation in Christmas celebration to Christians. The first group believes that saying congratulation on Christmas to Christians are not allowed, while the second group believes that Muslims are allowed to attend and congratulate Christmas to them. Historically, the Muslim has responded to the existence and the way of Christmas celebration similar to the way to commemorate the birthday of the Prophet (Prophet's Muhammad SAW birthday) and some mufti intend to prove Christmas celebration is heretic for Muslims.
\end{abstract}

Kata Kunci: ulama, fatwa, natal, maulid Nabi, akidah, toleransi 


\section{Pendahuluan}

Sejumlah orang Islam, khususnya yang tinggal di negara-negara yang didominasi oleh orang Kristen atau yang dipengaruhi oleh budaya Barat, berjuang dengan sikap mereka terhadap natal dan perayaannya, karena musim natal sangat menonjol di setiap aspek kehidupan seperti sekolah. Strategi pemasaran yang tinggi telah menginvansi rumah melalui televisi, radio, majalah, dan surat kabar sehingga mempengaruhi imajinasi orang dengan berbagai macam daya tarik siang dan malam selama satu bulan atau lebih setiap tahun. ${ }^{1}$ Umpamanya di Belanda, perjuangan ini adalah perjuangan yang paling menonjol sehubungan dengan anak-anak yang beragama Islam menghadiri natal atau yang sering disebut dengan ontmoetings school ${ }^{2}$ (sekolah pertemuan). Pertanyaan yang seringkali muncul apakah ada atau tidak mereka dipaksa untuk menghadiri atau mengucapkan selamat natal kepada orang Kristen pada hari perayaan natal mereka. Seorang imam di Amsterdam telah mencoba untuk menjawab pertanyaan apakah seorang Muslim boleh atau tidak merayakan natal dengan memberikan sebuah fatwa (ketetapan resmi atau sebuah anjuran agama) di mana dia memutuskan bahwa merayakan natal dilarang (tahrî̀m). ${ }^{3}$

Muslim yang ikut serta dalam perayaan natal bukanlah fenomena yang baru. Sepanjang sejarah Islam, telah diselenggarakan perayaan yang hebat untuk orang-orang Muslim yang tinggal di negara-negara yang minoritas Islam. Sejak awal abad ke 12 di Ceuta (sebelah utara negara Moroko ${ }^{4}$ ), orang-orang Kristen di Ceuta membuat pesta perayaan yang luar biasa, sehingga membuat orang Muslim yang berada di kota itu tertarik pada perayaan tersebut, sama halnya dengan orang-orang Muslim di Andalus yang tertarik pada perayaan natal. ${ }^{5}$ Di Mesir, pada hari natal Kristen kKoptik mendistribusikan permen untuk orang yang berkedudukan penting dari Kerajaan Fatimiyah. ${ }^{6}$ Pada abad ke-13, orang-orang Islam

${ }^{1}$ Saya berterima kasih kepada Prof. P. S. van Koningsveld dari Universitas Leiden-Belanda dan Prof. Herman L. Beck dari Universitas Tilburg-Belanda atas komentar-komentar kritis mereka pada teks ini.

${ }^{2}$ Ontmoetingsschool adalah sebuah sekolah di mana siswa-siswa yang mempunyai latar belakang agama yang berbeda-beda "bertemu." Karena itu, sekolah ini memerhatikan Islam pada pendidikan agama mereka. Akan tetapi, sekolah tersebut tetap sekolah Kristen, karena mereka tidak dapat mengizinkan "pertemuan" dengan yang lain pada pijakan yang berbeda, karena hal itu merupakan pengabaian ciri-ciri agama Kristen. Lihat W. A. R Shadid dan P. S. Koningsveld (ed.), The Integration of Islam and Hinduism in Western Europe (Netherlands: Kok Pharos, 1991), h. 161.

${ }^{3}$ Wawancara dengan Prof. van Koningsveld dari Universitas Leiden-Belanda.

${ }^{4}$ Kawasan sebelah utara Moroko dikenal sebagai penduduk Kristen dengan asal usul yang berbeda yang keluarganya tinggal di Ceuta pada awal abad ke 20. Herman L. Beck, "Christmas as Identity Maker, Three Islamic Examples," dalam P. Post dan CH. Caspers (ed.), Christians Feast and Festival: The Dynamic of Western Liturgy and Culture (Leuven-Peeters, 2001), h. 97-110.

${ }^{5} I b i d$., h. 103. Informasi ini diberikan untuk A. Ljamai yang sedang menyelesaikan disertasinya dengan judul Ibn Hazm et lla Yolemigue Islamo-Chretienne dans l'histoirel l'Islam.

${ }^{6}$ Nico. J. G. Kaptein, Muhammad's Birthday Festival, Early History in the Central Muslim Lands and Development in the Muslim West until the 10 $0^{\text {th }} / 16^{\text {th }}$ Century (Leiden: E. J. Brill, 1993), h. 28. 
di Ceuta ikut serta dalam perayaan pesta natal. Pada saat itu, penguasa Ceuta, Abû al-Abbas al-Azafi mencoba untuk menghilangkan keterlibatan orang Islam dalam perayaan natal dengan memperkenalkan maulid (perayaan kelahiran Nabi Muhammad SAW.) untuk orangorang Islam. Pada saat yang sama, ia juga ingin membentengi identitas orang Islam di Ceuta. ${ }^{7}$

Pada Februari 1981, isu Natal Bersama ${ }^{8}$ dikenal oleh orang Islam yang tinggal di Indonesia. Tujuannya adalah untuk menggalakkan keharmonisan antara orang Islam dan orang Kristen yang pada saat itu disebabkan oleh konflik di akhir tahun 1960an dan awal 1970an. Sejumlah orang di Indonesia melihat kejadian itu sebagai contoh yang baik dalam hal toleransi beragama, sementara banyak yang lainnya melihat sebagai upaya memperkenalkan orang Islam kepada Kristen atau untuk pengkristenan secara tidak langsung. Di bawah toleransi beragama, umat Kristen yang tinggal di Indonesia dengan senang hati mengundang orang Islam untuk menghadiri perayaan natal. ${ }^{9}$ Mereka berpendapat bahwa perayaan natal bukanlah suatu ritual, dan hal tersebut tidak sama dengan perayaan kelahiran Nabi Muhammad SAW. Beberapa orang Islam ada yang menjadi anggota panitia ${ }^{10}$ dalam perayaan natal. Keikutsertaan orang Islam merupakan kesempatan yang baik bagi orang Kristen untuk memperkenalkan mereka dengan agama Kristen. ${ }^{11}$ Karena itu, ilmuwan Muslim menilai penting untuk mengeluarkan sebuah fatwa. Misalnya fatwa yang dikeluarkan oleh Majelis Ulama Indonesia (MUI) yang ditandatangani oleh Syukri Gazali dan Mas'udi ${ }^{12}$ yang menyatakan bahwa seorang Muslim yang menghadiri perayaan natal merupakan sebuah pelanggaran (haram). Hamka juga berkomentar mengenai masalah ini, ${ }^{13}$ yang melarang umat Islam untuk menghadiri perayaan natal. Orang Kristen memercayai bahwa perayaan natal merupakan perayaan ulang tahun "anak Tuhan" yang dianggap sebagai perwujudan Tuhan mereka. Lebih lanjut, ia menegaskan bahwa itu merupakan kepercayaan umat Kristen, dan umat Islam mempunyai kepercayaan sendiri.

${ }^{7}$ Ibid., h. 91-95.

${ }^{8}$ Ungkapan natal bersama mengacu pada merayakan natal bersama orang Islam. Pelaksanaan natal nersama ini terjadi sebelum terjadinya kontroversi di antara orang Islam di Indonesia.

'Lihat Muhammad Atho Mudzhar, Fatwa-Fatwa Majelis 'Ulama' Indonesia: Sebuah Studi tentang Pemikiran Hukum Islam di Indonesia 1975-1988 (Jakarta: Mizan, 1993), h. 110. Lihat juga Karel Steenbrink, "Hamka (1908-1981) and the Integration of the Islamic Ummah of Indonesia," dalam Studia Islamika, Vol. 1, No 3, 1994, h. 142.

${ }^{10}$ Beberapa orang Islam bersedia untuk membantu menyiapkan natal dengan mendekorasi tempat untuk perayaan natal, dan pengorganisasian tempat parker.

${ }^{11}$ Mudzhar, Fatwa-Fatwa Majelis 'Ulama Indonesia, h. 110.

${ }^{12}$ Syukri Gazali dan Mas'udi, Ketua dan Sekretaris panitia fatwa dewan wilayah Jakarta, pada 1981.

${ }^{13}$ Hamka adalah singkatan dari Haji Abdul Malik Karim Amrullâh. Dia merupakan seorang ilmuwan Muslim Indonesia yang terkenal pada abad ke 20. Ia cukup unik dan multidimensi secara keilmuan. Banyak orang memandangnya tidak hanya sebagai ilmuwan Islam. Ia juga seorang wartawan, sejarawan, cendikiawan, agamis, dan pemimpin politik. Ketika fatwa orang Islam menghadiri perayaan natal dipublikasikan, ia merupakan Ketua Umum Majelis Ulama Indonesia. 
Jika seorang Islam menghadiri perayaan natal, berarti orang tersebut menjadi seorang musyrik. $^{14}$

Demikian pula dengan mengucapkan selamat kepada orang kafir pada perayaan natal dan perayaan agama lain dilarang menurut kesepakan ulama. Ibn al-Qayyim di dalam Ahkam Ahl al-Dzimma mengatakan "memberikan ucapan selamat kepada orang kafir pada perayaan yang hanya milik mereka adalah haram menurut hasil permufakatan. Orang Islam juga dilarang menirukan apa yang dikerjakan oleh orang kafir, menukar hadiah, memberikan permen atau makanan, atau mengambil waktu libur kerja". Ibn Taymiyyah mengatakan, "meniru orang Kristen dalam pesta mereka menyiratkan bahwa kita menerima keyakinan palsu dan praktik-praktiknya, dan memberi mereka harapan dan kesempatan untuk menghina dan menyesatkan orang-orang yang lemah keyakinannya". Hal ini benar ketika mereka ditaklukkan di bawah penghinaan jizyah (pungutan pajak atas non-Muslim pada awal-awal Islam). Untuk itu, mereka akan berpikir bahwa umat Islam harus dijadikan pembantu mereka di beberapa elemen dari iman mereka. ${ }^{15}$

Bertolak dari fakta di atas yang berasal dari aspek interaksi sosial masyarakat menjadi sebuah masalah atau debat bagi teolog sehingga timbul pertanyaan apakah umat Islam diizinkan atau tidak untuk mengucapkan selamat natal kepada umat Kristen pada perayaan agama mereka berdasarkan al-Qur'an dan hadis. Karena itu, sebuah ketetapan resmi dari orang yang berwenang mengenai pengizinan atau pelarangan untuk mengucapkan selamat natal kepada umat Kristen sangat diperlukan.

Di dunia Islam, dikenal ada dua jenis fatwa. ${ }^{16}$ Pertama fatwa yang dikeluarkan dari seorang ulama seperti fatwa dari Syaikh Muhammad Ibn Shalih al-Utsaymin, Ibn Taymiyyah, Ibn al-Qayyim, Muhammad Rasyid Ridha dan Muhammad Quraish Shihab. Kedua, fatwa dari kelompok ulama seperti fatwa yang dikeluarkan dari majelis tertinggi ahli hukum dari Kerajaan Arab Saudi, fatwa dari Majelis Eropa dan Majelis Ulama Indonesia (MUI). Kebanyakan fatwa di dunia Islam dikeluarkan atas tanggapan masalah dari masyarakat Muslim. Beberapa fatwa dikeluarkan suka rela oleh ulama sebagai petunjuk untuk pemerintah atau untuk orang yang beriman, dan yang lainnya dipublikasikan di bawah permintaan pemerintah ketika fatwa tersebut diperlukan, ulama memberikan saran tentang kebijakan yang terkait dengan masalah keagamaan. Dengan demikian, fatwa dikeluarkan dalam berbagai keadaan dan untuk berbagai kegunaan.

Tulisan ini mengkaji fatwa para ulama yang berkaitan dengan pengucapan selamat

${ }^{14}$ Rusydi Hamka, Pribadi dan Martabat Buya Prof. Dr. Hamka (Jakarta: Pustaka Panjimas, 1981), h. 192.

${ }^{15}$ Lihat Muhammad Umar Memon, Ibn Taymiyy's Struggle Against Popular Relegion (Paris: Hague, 1976), h. 216-217.

${ }^{16}$ Fatwa adalah anjuran agama yang diberikan oleh seorang mufti (pemberi fatwa) atas permintaan satu orang atau lebih orang Islam yang menanggapi adalah mufti sebagai orang yang berkuasa. Pemberi fatwa disebut ifta, sedangkan peminta fatwa disebut istiftâ'. 
kepada umat Kristen atas perayaan natal mereka. ${ }^{17}$ Lebih lanjut akan dicoba untuk menjelaskan mengapa fatwa ini dikeluarkan. Selain itu, juga akan dilihat beberapa diskusi tentang pendapat ilmuwan Muslim tentang mengucapkan selamat natal kepada Kristen serta bagimana reaksi dunia Muslim tetang perayaan natal tersebut.

\section{Hubungan Sosial Politik dari Fatwa}

Fatwa tentang perayaan natal dikeluarkan berhubungan dengan perayaan tahun ketiga millennium, ${ }^{18}$ pembahasan tentang persaingan antara misi Kristen, dan pembahasan tentang kedatangan orang Islam pada perayaan natal. Fatwa tersebut dipublikasikan berkenaan dengan pertanyaan tentang merayakan millennium dan diajukan kepada mufti yang berkedudukan tinggi dan diteruskan kepada panitia tetap dewan tinggi ulama (No. 3825, tanggal 21/Rajab/1420 hijriah atau 1 September/1999 masehi). ${ }^{19}$ Pertanyaannya, "bagaimana seharusnya umat Islam menyiapkan dirinya untuk menyambut kedatangan tahun baru?" Pertanyaan ini pernah diajukan kepada Syaikh Muhammad bin Shalih al-Utsaymin sebagai seorang mufti (pemberi fatwa) untuk mengetahui keputusan syar'i (hukum Islam) mengenai masalah ini. Istifta' (peminta fatwa) adalah majelis tertinggi ahli hukum dari Kerajaan Arab Saudi atas nama umat Islam.

Untuk menyambut awal millennium ketiga kalender masehi, umat Islam memperhatikan bahwa di sana terdapat banyak laporan tentang peristiwa dan persiapan besar untuk menyambut tahun 2000 CE (Christian Era). Orang Yahudi dan Kristen sangat gembira mengenai hal ini, dan mereka menyematkan harapan besar dari peristiwa ini. ${ }^{20}$ Umat Kristen sedang menyiapkan untuk perayaan tahun 2000 menurut kelender mereka, mereka membuat persiapan yang luar biasa untuk selanjutnya mereka rencanakan dan menyebarkan keyakinan mereka kepada seluruh orang di dunia, khususnya di Amerika Serikat. Beberapa orang Islam juga menunjukkan ketertarikan mereka tentang peristiwa ini, dan hal ini dianggap sebagai waktu yang tepat untuk melangsungkan pernikahan atau melakukan sesuatu hal. Beberapa dari mereka mengiklankan peristiwa ini di toko atau perusahaan mereka. Selain itu, beberapa orang Islam telah dipengaruhi oleh propaganda ini, dan mereka mulai menyiapkan sesuatu untuk perayaan mereka, seperti menawarkan potongan harga dalam rangka peristiwa ini. Ada kekhawatiran bahwa hal ini akan berdampak pada keyakinan umat Islam. Dalam hal ini, majelis tertinggi ahli hukum dari Kerajaan Arab Saudi atas nama

\footnotetext{
${ }^{17}$ Lihat majelis tertinggi, ahli hukum dari kerajaan Arab Saudi, The Council of Supreme Body of Jurists of the Kingdom of Saudi Arabia, Fatâwâ al-Bilâd al-ㅍarâm (Saudi Arabia: 1999), h. 9697.

${ }^{18}$ Millennium pertama dimulai pada $\mathrm{AD}$ (Anno Domini) 1. Jadi millennium dihitung dengan cara berikut: millennium pertama: 1-1000, millennium kedua: 1001-2000, dan millennium ketiga: 2001-3000. Dengan demikian, millennium ketiga sama dengan abad ke 21 yang dimulai pada bulan Januari pada tahun 2001.

${ }^{19}$ Lihat http://groups.yahoo.com/group/dih-list/message/19.

${ }^{20}$ Ibid.
} 
umat Islam menerbitkan fatwa mengenai keputusan merayakan tahun baru 2000, menyatakan bahwa hal itu tidak dibolehkan atau diizinkan bagi umat Islam untuk mengikuti berbagai kegiatan dalam menyambut tahun millenium baru dan menggunakan kalendar masehi. ${ }^{21}$ Dapat dikatakan bahwa umat Islam dilarang untuk merayakan dan meniru berbagai kegiatan umat Kristen seperti menyambut millennium baru dan perayaan umat Kristen lainnya.

Selain masalah ini, hal lain yang dianggap memiliki hubungan sosial politik dengan fatwa dengan perayaan natal, misalnya, kejadian yang terjadi pada umat Islam Indonesia yang mengambil bagian dalam perayaan natal. Perayaan natal di Indonesia adalah sebuah perayaan yang meriah di mana nyanyian puji-pujian terdengar di mana-mana, dan suasana natal menembus kehidupan masyarakat sehari-hari. Otoritas Islam di Indonesia khawatir perayaan natal akan menjadi godaan yang kuat untuk mempengaruhi umat Islam yang ikut merayakan natal, karena natal telah dikenal dalam keluarga dan dalam kehidupan umum. $^{22}$

Dalam perayaan natal di Indonesia, orang Islam sering diundang untuk merayakan natal dengan senang hati. Mereka menerima undangan tersebut dengan berbagai macam alasan. Salah satu alasannya adalah keinginan dari kebanyakan orang Indonesia untuk hidup harmonis dengan sesama penduduk Indonesia. Beberapa kegiatan perayaan natal di Indonesia tidak lagi menjadi perdebatan, misalnya mengujungi panti asuhan Matahari Terbit, mengunjungi rumah orangtua, menyumbangkan pakaian bekas untuk panti Werdha, serta menyumbangkan uang untuk membeli makanan. Alasan lainnya adalah memiliki anggota keluarga yang berbeda keyakinan atau agama bukanlah kejadian yang luar biasa di Indonesia, dan tidak menyebabkan masalah. Biasanya, anggota keluarga yang lain menghadiri perayaan keagamaan anggota keluarga lain yang berbeda keyakinan. ${ }^{23}$ Contohnya, salah satu kepala keluarga, Musthofa al-Habsy di Solo Indonesia, menyelenggarakan perayaan natal pada tanggal 25 Desember 2008 di rumahnya, dan dia mengundang tetangganya (tidak peduli mereka Islam atau tidak) untuk menikmati makanan istimewa yang disebut tumpengan pada saat perayaan natal. ${ }^{24}$

Dalam tataran empirik, bangsa Indonesia terdiri atas berbagai agama, sehingga menghadiri perayaan agama lain dinilai sebagai salah satu cara untuk menghormati umat agama lain yang mengundang. Praktik tersebut dapat meningkatkan persatuan nasional dan integritas, serta keharmonisan di antara pemeluk agama yang berbeda. ${ }^{25}$ Pemerintah

${ }^{21}$ Ibid.

${ }^{22}$ Lihat Mudzar, Fatwa-Fatwa Majelis Ulama Indonesia, h. 107.

${ }^{23}$ Lihat Beck, "Christmas as Identity Maker," h. 107.

${ }^{24}$ Pada perayaan tersebut, Musthofa al-Habsy mengatakan bahwa tidak ada larangan dalam Islam untuk merayakan kelahiran Nabi Isa (Yesus Kristus) yang juga diakui sebagai Nabi dalam agama Islam. Lihat detik.com pada 25 Desember 2008.

${ }^{25}$ Pendapat menteri Agama dalam berita berkala Indonesia, lihat Tempo, 30 Mei 1981, h. 13-14. 
Indonesia melihat hal tersebut sebagai sesuatu yang lazim untuk menghadiri perayaan agama lainnya dalam rangka untuk mempertahankan kesatuan dan integritas nasional. ${ }^{26}$ Namun, MUI dan organisasi Muslim, Nahdlatul Ulama dan Muhammadiyah mengingatkan pejabat pemerintah yang menghadiri perayaan natal untuk memisahkan antara ritual dan seremonial dari perayaan tersebut agar iman orang Islam terlindungi.

\section{Diskursus Pendapat Ulama tentang Perayaan Natal}

Dalam hal ini, dinilai perlu untuk mendiskusikan pendapat ilmuwan Muslim terhadap masalah ini. Untuk mengetahui perdebatan di antara ilmuwan Muslim dalam hal memberikan ucapan selamat kepada umat Kristen dalam perayaan natal mereka atau ikut serta dalam hari besar keagamaan umat Kristen. Pendapat-pendapat ilmuwan Muslim dalam masalah ini dapat memperluas pemahaman dari fatwa itu sendiri. Untuk tujuan ini, akan didiskusikan pendapat-pendapat ilmuwan Muslim.

\section{Pendapat Muhammad bin Shalih al-Utsaymin}

Syaikh al-Utsaymin, seorang ulama Saudi Arabia, pernah ditanya apakah status hukum tentang mengucapkan selamat natal kepada umat Kristen? Bagaimana cara menanggapinya? Apakah diizinkan untuk pergi ke tempat di mana mereka merayakan peristiwa ini? Apakah berdosa jika seseorang melakukan sesuatu yang di atas dengan ketidaksengajaan, tetapi salah satu cara sopan santun atau tidak memalukan atau menyakiti perasaan orang lain atau untuk alasan lainnya? Ia menjawab bahwa "ucapan selamat kepada umat Kristen dalam perayaan natal atau perayaan keagamaan lainnya dilarang oleh hasil kesepakatan ulama yang disebutkan oleh Ibn al-Qayyim dalam kitabnya Ahkâm Ahl al-Dzimmah. Ia mengatakan bahwa memberikan ucapan selamat atas perayaan praktik-praktik pemujaan orang Kristen dilarang berdasarkan kesepakatan ulama, contohnya, mengucapkan selamat kepada mereka dengan mengatakan "selamat atas perayaan untuk kamu" atau "selamat menikmati perayaan anda", dan sebagainya. Jadi, dilarang untuk mengucapkan selamat kepada orang kafir. Sama halnya seperti mengucapkan selamat kepada seseorang bersujud kepada salib, atau sesuatu yang lebih buruk. Merupakan dosa besar seperti mengucapkan selamat kepada orang minum air anggur yang memabukkan, membunuh seseorang, atau memiliki hubungan yang terlarang. Banyak orang yang tidak peduli dengan agamanya telah melakukan kesalahan ini. Mereka tidak menyadari kesalahan dari perbuatan mereka. Barangsiapa yang mengucapkan selamat kepada seseorang yang tidak beriman atau pelaku bidah atau orang kafir berarti membuka dirinya kepada kemurkaan dan kemarahan Allah.

${ }^{26}$ Lihat Pelita, 6 Mei 1981, h. 1; Kompas, 8 Mei 1981, h. 12. Menteri Agama pada saat itu, H. Alamsyah Ratu Perwiranegara yang memberikan komentar mengenai fatwa dengan mengatakan bahwa fatwa dibuat berdasarkan ayat-ayat al-Qur'an dan kebiasaan Nabi, sedangkan dari aspek sosial tidak dipertimbangkan. 
Mengapa orang Islam tidak boleh mengucapkan selamat kepada orang kafir atas perayaan keagamaan seperti yang dijelaskan oleh Ibn al-Qayyim? Karena hal ini menyiratkan satu penerimaan atau penyetujuan ritual/peribadatan orang kafir. Seorang Muslim tidak dapat menerima peribadatan orang kafir untuk dirinya sehingga mereka harus menolak ritual orang kafir dan menolak mengucapkan selamat kepada mereka. Allah berfirman: "Jika kamu kafir maka sesungguhnya Allah tidak memerlukan (iman)mu dan Dia tidak meridai kekafiran bagi hamba-Nya; danjika kamu bersyukur, niscaya Dia meridhai bagimu kesyukuranmu itu....” (Q.S. al-Zumar/ 39: 7) “...Pada hari ini telah Ku-sempurnakan untuk kamu agamamu, dan telah Ku-cukupkan kepadamu nikmat-Ku, dan telah Ku-ridai Islam itu jadi agama bagimu...” (Q.S. al-Mâ'idah/ 5: 3)

Syaikh al-Utsaymin menyimpulkan bahwa mengucapkan selamat kepada orang kafir dilarang, meskipun mereka salah seorang rekan kerja atau yang lainnya. Jika mereka menyambut seorang Muslim pada perayaan keagamaan mereka, ia seharusnya tidak membalasnya karena itu bukan perayaan kepercayaannya, dan karena perayaan tersebut tidak diterima oleh Allah. Perayaan ini merupakan bagian dari kepercayaan mereka dan bahkan mereka telah merencanakannya, pada dasarnya telah dibatalkan oleh agama Islam dan Allah mengirimkan Nabi Muhammad SAW. kepada seluruh umat manusia. Allah berfirman, "Barangsiapa yang mencari agama selain agama Islam, tidak akan diterima (agama itu), dan dia di akhirat menjadi orang-orang yang rugi." (Q.S. Ali 'Imrân/3: 85). Adalah terlarang bagi seorang Muslim untuk menerima undangan perayaan keagamaan mereka karena ini merupakan lebih buruk daripada memberikan ucapan selamat kepada mereka karena hal ini juga berarti mengambil bagian dari perayaan mereka.

Sama halnya dengan orang Islam dilarang untuk meniru orang Kristen seperti saling tukar hadiah, memberikan makanan atau permen, mengambil waktu libur kerja, dan sebagainya. Karena Nabi Muhammad SAW. bersabda: "Barangsiapa yang mengikuti satu kaum, maka dia digolongkan dalam kaum itu.”(H.R. Imam Ahmad). Syaikh Ibn Taymiyyah berkata dalam kitabnya, Iqtidâ' al-Sirât al-Mustaqîm Mukhâlaf Ashâb al-Jahîm, meniru mereka dalam perayaan menyiratkan bahwa seseorang senang dengan kepercayaan dan perbuatan salah yang mereka kerjakan, dan memberikan mereka harapan bahwa mereka mempunyai kesempatan untuk mengubah kepercayaan dan menyesatkan orang yang lemah imannya. Barangsiapa yang melakukan hal seperti ini adalah orang yang berdosa, apakah seseorang itu melakukannya di luar norma kesopanan atau penuh persahabatan atau karena seseorang takut menolaknya atau disebabkan oleh alasan lain, karena ini adalah kemunafikan di dalam Islam, dan hal ini juga dapat membuat orang Kristen merasa bangga dengan agama mereka. ${ }^{27}$

\footnotetext{
${ }^{27}$ Lihat Muhammad Ibn Shalih al-Utsaymin, "al-Tahni'a bi 'Id al-Krismâsi," dalam The Council

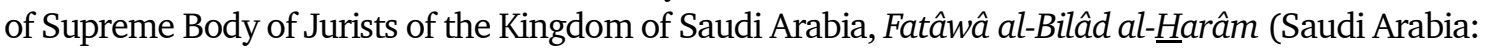
1999), h, h. 96-97.
} 
Tidak ada keraguan bahwa fatwa tersebut sangat kuat, sejalan dengan penjelasan dari al-Qur'an dan hadis. Namun, fatwa itu tidak mengacu pada naskah atau bacaan dengan penjelasan luas atau klasik dengan perkembangan terakhir dalam masyarakat Muslim majemuk di dunia. Banyak penulis kontemporer dengan salah satu cara atau lainnya telah membahas pertanyaan tersebut, meskipun mereka tidak menghubungkan dengan aspek hukum atas pertanyaan tersebut. ${ }^{28}$

\section{Pendapat Ibn Taymiyyah ${ }^{29}$}

Menurut Ibn Taymiyyah, memberi ucapan selamat pada perayaan non-Muslim pada hari besar agama mereka adalah dilarang. Menyetujui hari besar agama mereka berarti menyetujui untuk kekafiran, dan menyetujui beberapa aspek kecil dari agama mereka adalah seperti menyetujui sebuah cabang dari kekafiran. Larangan juga diperluas kepada semua hal yang berkaitan kepada perayaan, seperti, memberikan hadiah dan makanan.

Ibn Qayyim juga mempunyai pendapat yang sama, di mana memberi ucapan selamat pada orang kafir pada perayaan agama mereka adalah dilarang oleh konsensus karena menyiratkan bahwa seseorang menerima atau menyetujui dari ritual kekafiran mereka. Demikian pula dengan Fatwa Lajna Daima li al-Buhûts al-'Ilmiyya wa al-Iftâ'. Fatwa ini menyatakan bahwa Muslim tidak diperbolehkan untuk mengucapkan selamat kepada orangorang Kristen pada hari raya mereka. Lebih lanjut, fatwa ini menjelaskan bahwa ada unsur dosa dalam praktik seperti itu yang dilarang dalam Islam. Muhammad Rasyid Ridha juga menyatakan pembahasan yang sama dalam fatwanya yang melarang Muslim untuk

${ }^{28}$ Maqrizi menyebutkan fakta bahwa pada saat itu dinasti Fatimiyah (909-1171 A.D), orangorang Mesir merayakan perayaan natal dengan beberapa orang Islam terlibat dalam penyiapan makanan, tetapi dia tidak menyebutkan status hukum dari keterlibatan beberapa orang Islam tersebut. Ibn Taymiyyah (ca. 1263) melihat hanya penulis pada zaman dahulu yang menyetujui dengan aspek hukum mengenai keikutsertaan orang Islam dalam perayaan natal. Dalam kibabnya, Iqtidâ' al-Sirât al-Mustaqîm Mukhâfalah Ashh彑âb al-Jahîim, dia menyatakan bahwa meniru perayaan natal, dengan pengetahuan tentang itu adalah maksud dari peniruan adalah iman keyakinan juga ikut serta dalam perayaan tersebut dilarang. Abu al-Abbâs al-'Azafi mengakui bahwa pengenalan dengan perayaan maulid kepada umat Islam pada di Maghrib justru untuk meniadakan keikutsertaan orang Islam dalam perayaan natal. Lihat P. Shinar, "Traditional and Reformist Mawlid Celebrations in the Maghrib," dalam Myryam Rosen-Ayalon (ed.), In Memory of Gaston Wiet (Jerussalem: t.p., 1977), h. 278. Karena intens persaingan Islam-Kristen sepanjang sejarah, hal ini memungkinkan bahwa fukaha lainnya merespons mengenai pertanyaan ini.

${ }^{29}$ Ibn Taimiyah adalah Ahmad Ibn 'Abd al-Salâm Ibn 'Abdullâh, Abû al-Abbas Taqi' al-Dîn Ibn Taimiya al-Harrani, lahir di Harran, di timur Damaskus pada 10 Januari 1263. Ia adalah seorang yang terkenal dari Ulama Hanbali dalam menafsirkan al-Qur'an, hadis dan ilmu hukum. Ia adalah seorang pembaca yang "rakus" dan penulis yang mempunyai pribadi keteguhan hati yang besar yang memiliki gaya penulisan yang menarik dan memori yang tajam. Salah satu dari kitabnya yang terkenal adalah Iqtidâ' al-Sirât al-Mustaqîm Mukhâfalah Ash hâab al-Jahîm. Ia meninggal di Damaskus pada 29/28/26 September 1328. 
mengambil bagian dalam perayaan agama non-Muslim. ${ }^{30}$ Selain itu, Jamal al-Dîn Zarabozo menegaskan lebih lanjut bahwa Muslim tidak diperbolehkan untuk mengucapkan selamat pada hari libur atau perayaan/festival non-Muslim karena kegiatan tersebut dianggap dilarang oleh kesepakatan ulama Islam. Tindakan ini dianggap menghormati orang Kristen serta membantu mereka dalam kesyirikan, kegiatan tersebut tidak memiliki dasar dalam hukum Islam. ${ }^{31}$ Dengan demikian, hukum menyampaikan ucapan selamat kepada non-Muslim pada hari besar agama mereka adalah dilarang.

\section{Pendapat M. Quraish Shihab ${ }^{32}$}

M. Quraish Shihab membahas dua pandangan berbeda tentang mengucapkan selamat natal untuk orang Kristen. Pertama, ia menguraikan tentang pendapat yang membolehkan umat Islam untuk mengucapkan selamat natal untuk rekan-rekan Kristen mereka. Untuk mendukung pendapat ini, ia mencoba menguraikan titik persamaan antara Yesus Kristus (Isa al-Masih) dan Muhammad. Berdasarkan al-Qur'an, Isa adalah rasul Allah (Q.S. Ali 'Imrân/ 3: 49). Ia sama seperti Muhammad dan nabi-nabi lain. Al-Qur'an juga mengabadikan dan mengatakan selamat natal kepada Nabi Isa dan mengucapkan selamat/mengakui bahwa Isa pada hari kelahirannya, kematian, dan kenaikan (Q.S. Maryam/19: 33). Muslim harus percaya kepada Isa dan Muhammad karena keduanya adalah hamba serta Rasul Allah. Ia mengutip sebuah hadis, yang menyatakan bahwa Nabi Muhammad juga merayakan keselamatan Musa dari gangguan/ancaman Firaun dengan berpuasa 'asyura. Terlebih lagi, ia mengutip hadis lain yang menyatakan bahwa semua nabi adalah bersaudara. Tidak ada perbedaan di antara mereka. Berdasarkan pesan dalam al-Qur'an, pada akhirnya ia menekankan bahwa Isa dan Muhammad adalah orang biasa. ${ }^{33}$ Argumen yang mendasar di atas menyiratkan salah satu titik persamaan antara Muhammad dan Isa. Ini juga isi dari kalimat salwa bahwa al-Qur'an menawarkan kepada orang Kristen dan Yahudi (Q.S. Ali 'Imrân/3: 68). Argumen ini mendukung argumen lain bahwa Muslim diperbolehkan untuk

${ }^{30}$ Lihat Nurhadi, Muslim's Attendence at Christmas Celebration: A Study on the Fatwa of the Council of Indonesian 'Ulama', (paper tidak diterbitkan, 1998), h. 35.

${ }^{31}$ Lihat Jamal al-Din Zarabozo, "Celebrating or Participating in Holidays of the Disbelivers," dalam Majalah al-Jumu'ah, Vol. 9, Issue 2.

${ }^{32}$ Muhammad Quraish Shihab lahir di Rappang, Sulawesi Selatan (Ujung Pandang), Indonesia. Setelah menyelesaikan pendidikan keduanya di Malang, ia ke Kairo untuk program pascasarjana. Di tahun 1967, ia menyelesaikan program prasarjana dengan jurusan Tafsir dan Hadis di Fakultas Ushuluddin. Di tahun 1969, ia menyelesaikan program sarjana jurusan penafsiran al-Qur'an di fakultas yang sama di Universitas al-Azhar. Pada tahun 1980, ia menyelesaikan program pasca sarjana dari Universitas tersebut di bidang Ilmu Quran. Kembali ke Indonesia, ia menduduki sejumlah posisi penting seperti Rektor Institut Agama Islam Jakarta, dan Ketua Majelis Ulama Indonesia. Ia menjadi Menteri Agama pada kabinet terakhir Presiden Suharto. Ia menulis banyak buku. Salah satunya adalah Membumikan al-Qur'an.

${ }^{33}$ Lihat M. Quraish Shihab, Membumikan al-Qur'an (Bandung: Mizan, 1992), h. 370-371. 
mengucapkan selamat dan menghadiri perayaan natal selama Muslim dapat menjaga iman mereka.

Kedua, ada pendapat yang menyatakan bahwa natal ini dimaksudkan sebagai suatu peringatan kelahiran Isa yang dianggap oleh kebanyakan dari mereka sebagai penjelmaan Tuhan. Sudut pandang ini benar-benar berbeda dengan Muslim di mana seluruh kaum Muslim melihat bahwa Isa adalah orang biasa. Karena itu, mengucapkan selamat pada hari natal dapat membahayakan iman orang Islam. Praktik ini dapat dipahami sebagai pengakuan terhadap ketuhanan Isa yang sepenuhnya bertentangan dengan akidah Islam.

\section{Pendapat Husein Shahab ${ }^{34}$}

Pendapat Husin Shahab didasarkan pada kesimpulan dari diskusi tentang partisipasi Muslim pada natal. Kesimpulannya ada dua. Pertama, 25 Desember adalah bukan tanggal yang tepat untuk hari kelahiran Nabi Isa. Kedua, tidak ada teks al-Qur'an tentang natal, juga tidak ada argumen yang pasti berasal Nabi Muhammad SAW. atau imam yang mengatakan bahwa orang harus memberi penghormatan pada hari natal. Karena itu, merayakan natal dikategorikan sebagai bidah. ${ }^{35} \mathrm{Di}$ samping itu, mengacu pada kesimpulan dan pengalaman Ayatullah Khomeini ketika ia diasingkan, Shahab kemudian memutuskan bahwa hukum merayakan natal menjadi dua. Pertama, bagi Muslim, tidak ada pendapat atau pedoman untuk melakukannya. Kedua, jika ada manfaat dalam melakukannya, misalnya untuk membangun rasa saling menghormati antara Islam dan Kristen, maka hukumnya menjadi ja'iz. ${ }^{36}$ Informasi yang serupa mengenai mengucapkan selamat kepada orang Kristen untuk membangun saling menghormati dan persatuan antara Islam dan Kristen dikeluarkan oleh Imam Pakistan, Syed Sâdat 'Ali Qadri yang mengatakan bahwa setiap Muslim seharusnya mengucapkan selamat. Ia ingin mengingatkan masyarakat Muslim bahwa Muhammad dan Isa adalah dekat. Itu sebabnya Muslim dan Kristen seharusnya berusaha untuk bersatu mengusir kekuatan komunis medan kapitalisme. Dalam hal ini, merayakan natal tidak diperselisihkan. ${ }^{37}$

\section{Reaksi Dunia Muslim terhadap Perayaan Natal}

Dalam bagian ini, akan didiskusikan reaksi dunia Muslim terhadap perayaan natal.

${ }^{34}$ Husein Shahab adalah seorang Muslim yang tinggal di Qom, Iran. Ia diundang beberapa ulama Islam untuk mendiskusikan masalah yang berhubungan dengan partisipasi Muslim dalam perayaan natal.

${ }^{35}$ Lihat artikel Husein Shahab dalam majalah Tempo, 1 Agustus 1991, h. 6.

${ }^{36}$ Suatu tindakan dianggap netral terhadap perintah Allah yang mungkin atau mungkin tidak dilakukan dimana tida ada kerugian atau kebaikan terjadi. Sinonim dari ja'iz adalah mubah.

${ }^{37}$ Nico Landman, Visies van Moslims in Nederlands op de Christenen en de Kerkedijke Houding Tenover Moslims, (Dotoraalscriptie Missiologie Faculteit der Godgeleerdheid, Vrije Universiteit Amsterdam, 1986), h. 50. 
Tentu saja dalam sejarah Islam, perayaan natal selalu menarik bagi setiap Muslim. Ada beberapa upaya untuk menghalangi orang Muslim berpartisipasi dalam perayaan natal. Ditemukan paling tidak ada dua cara orang Islam memberi reaksi terhadap perayaan natal yaitu, dengan merayakan perayaan kelahiran Nabi Muhammad SAW. dan membuktikan perayaan natal bidah bagi Muslim dengan menerbitkan fatwa.

\section{Merayakan Perayaan Kelahiran Nabi Muhammad SAW.}

Dalam sejarah Islam, reaksi dunia Muslim terhadap natal adalah dengan mengimbanginya dengan perayaan kelahiran Nabi Muhammad SAW. Perayaan natal dikatakan memiliki pengaruh dalam asal-usul perayaan kelahiran Nabi Muhammad SAW. Pendapat ini lebih jelas sebagai berikut:

Perayaan natal itu dengan dengungan di pasar-pasar, pameran negara, bunga, lilin. Mereka berdesak-desakan, kerumunan kegembiraan tidak hanya menjadi sebuah acara sosial yang penting dalam kehidupan Islam populer tetapi juga telah menjadi kecenderung anasli untuk memuliakan Nabi Islam dalam bentuk seperti perayaan maulid, dirayakan dalam rangka memperingati hari kelahiran Nabi Muhammad SAW. ${ }^{38}$

Dalam sumber yang sama, pendapat lain dinyatakan dengan cara sebagai berikut:

Dalam perjalanan waktu sampai ke titik di mana banyak Muslim, selama perayaan non-Muslim ... telah menjadi kebiasaan berkumpul di tempat-tempat pertemuan besar, mewarnai telur, memasak susu, menandai binatang mereka dengan warna merah, menyiapkan makanan, seperti hampir tidak pernah disiapkan selama perayaan Islam. ${ }^{39}$

Perayaan natal di dunia Muslim menjadi popular sehingga otoritas Muslim merasa terdorong untuk mengambil tindakan untuk mengimbanginya. Dalam kasus Abû al-'Abbas I-'Azafi ${ }^{40}$ di Ceuta, ia dipercaya telah memperkenalkan perayaan kelahiran Nabi Muhammad SAW. di bagian Barat dunia Muslim sebagai reaksi terhadap keikutsertaan Muslim pada perayaan natal. Ia memperkenalkan maulid untuk mengalihkan perhatian dari teman seagamanya supaya jauh dari perayaan natal. ${ }^{41}$ Dengan kata lain, ia mencoba untuk menghilangkan keterlibatan Muslim dalam perayaan Kristen dengan memperkenalkan maulid dalam rangka untuk membatalkan berbagai perayaan Kristen dan untuk memperkuat identitas Muslim di Ceuta. Ia telah mengisahkankan tentang ini dengan menulis bahwa ia ingin”... untuk mengatasi kebiasaan yang diadopsi oleh Muslim dari keteguhan berpartisipasi dalam

${ }^{38}$ Lihat Memon, Ibn Taymiyya's Struggle, h. 2.

${ }^{39}$ Ibid., h. 213.

${ }^{40}$ Abû al-Abbas I-Azafi hidup sejak 17 Ramadhân 557/30 Agustus 1162 sampai 7 Ramadhân 633/16 Mei 1236 di Ceuta. Ia menduduki posisi hakim pengadilan agama. Ia dikenal ahli dalam bidang hukum, kesusasteraan tradisional, teologi, dan ilmu tasawuf. Ia mengajar di masjid besar di Ceuta sepanjang hidupnya.

${ }^{41}$ Lihat Kaptein, Muhammad's Birthday Festival, h. 88-89. 
perayaan natal dari penduduk Kristen setempat, termasuk malam natal". ${ }^{42}$ Dalam rangka membuat keputusan yang cukup beralasan, ia mengatakan bahwa Allah mengetahui niatnya dan menyadari motifnya dan Dia Maha Tinggi dengan rencana-Nya yang akan menjadi argumen yang menentukan baik dalam agama dan bidang umum. ${ }^{43}$ I-Azafi menulis Durr al-Mu'azzam ${ }^{44}$ dalam rangka untuk menyebarluaskan perayaan maulid di Ceuta. Karena itu, selama hidupnya, perayaan maulid diadakan lebih umum, tetapi ia tidak berhasil menghapuskan perayaan-perayaan Kristen karena tidak mungkin bahwa maulid bisa menggantikan perayaan Kristen. ${ }^{45}$ Adalah suatu keniscayaan bahwa maulid itu dirayakan menurut kalender peredaran bulan (hijriah), sedangkan perayaan natal dirayakan menurut kelender masehi. Karena itu, tanggal perayaan maulid selalu berbeda setiap tahun dengan tanggal perayaan natal.

\section{Membuktikan Perayaan Natal Bidah bagi Muslim}

Ibn Taymiyyah, Ibn Qayyim, dan Muhammad Rasyid Ridha telah membuktikan bahwa natal adalah bidah bagi Muslim. Mereka melarang Muslim untuk memberi ucapan selamat kepada Kristen saat perayaan natal. Itulah sebabnya mengapa Muslim harus menjaga diri mereka terpisah selama perayaan natal. Dari tiga ilmuwan Muslim ini, Ibn Taymiyyah (12631328) memiliki pandangan yang paling menonjol dan berpengaruh. Ia adalah seorang yang tidak kenal lelah memperjuangkan nilai-nilai Islam ortodoks dan standar. Dalam berbagai tulisannya, ia mengecam pelanggaran agama dan sosial yang ia amati di antara sesama Muslim. Menurut Ibn Taymiyyah, salah satu kejahatan yang mengancam kemurnian dan keutuhan komunitas Muslim adalah pesta hari raya Kristen yang dimiliki oleh umat Islam. ${ }^{46}$ Namun demikian apa yang ia berantas, "tidak begitu banyak tentang partisipasi Muslim dalam tindakan utama beribadah, terpisah dari perjalanan dalam prosesi yang populer pada hari raya natal, tampaknya tidak terjadi", tapi "partisipasi umat Islam dalam peristiwa sekunder yang mengelilingi pesta tersebut". ${ }^{47}$

Ibn Qayyim mengutuk Muslim dalam kitabnya, Ahkâm Ahl al-Dzimma, yang mengucapkan selamat kepada orang kafir pada perayaan keagamaan mereka. Demikian pula gurunya, Ibn Taymiyyah, dalam kitabnya, Iqtidâ al-Sirât al-Mustaqim Mukhâlafat Ashab

${ }^{42}$ Lihat Shinar, "Traditional and Reformist Mawlid Celebration in Maghrib," h .76.

${ }^{43}$ Kaptein, Muhammad's Birthday Festival, h. 83.

${ }^{44}$ al-Durr al-Mu'azzam fí Mawlid al-Nabi al Mu'azzam adalah nama kitab yang abû al-'Abbâs I-Azafi tulis untuk menyebarluaskan perayaan mauled nabi di Ceuta. Tetapi dia meninggal sebelum menyeselaikannya. Namun demikian, tugas ini diselesaikan oleh anaknya, Abû al-Qâsim al-Azafi yang juga melanjutkan penyebarluasan perayaan kelahiran Nabi Muhammad ke seluruh wilayah di Magrib. Lihat Kaptein, Muhammad's Birthday Festival, h. 89.

${ }^{45}$ Ibid., h. 91.

${ }^{46}$ Lihat Beck, "Christmas as Identity Maker, h. 104.

${ }^{47}$ Lihat Thomas F. Micheal, A Muslims Theologian's Response to Christianity Ibn Taymiyya's al-Jawab al-Shahih, terj. Thomas F. Micheal (Delmar/New York, 1984), h. 82. 
al-Jahîm. ${ }^{48}$ Ia mempertahankan pendapat bahwa ada dua perayaan dalam Islam, yaitu perayaan Idul Fitri dan perayaan Idul Adha yang diakui oleh hukum Islam, sementara perayaan lainnya adalah bagian dari agama populer. Berbagai macam fenomena perayaan dapat didefinisikan berdasarkan unsur waktu, lokasi, dan ritual. Pendapat ini mengidentifikasikan bahwa ia menunjukkan natal bersifat non-Islami. Penjelasan yang lebih jelas dinyatakan dalam kalimat-kalimat berikut:

Perayaan yang dilakukan oleh banyak orang selama musim dingin pada 25 Desember yang mereka klaim sebagai hari kelahiran Yesus jatuh di bawah tujuan yang sama. Menyalakan api, menyiapkan makanan, menyalakan lilin, singkatnya, semua praktik hari tersebut jelek. Membuat sebuah perayaan di luar hari kelahiran adalah kultus Kristen dan tidak memiliki dasar dalam keyakinan Islam. Sama sekali tidak disebutkan dan ditemukan dalam masa salaf (referensi ke komunitas awal Islam dan cara mereka dalam keyakinan dan perilaku). ${ }^{49}$

Ibn Taymiyyah juga menyebutkan bahwa Muslim tidak boleh membantu dalam perayaan natal dalam satu cara atau lainnya. Misalnya seseorang seharusnya tidak menjual apapun pada orang Kristen yang mungkin akan mereka gunakan selama perayaan. Contohnya daging atau pakaian juga tidak seharusnya Muslim meminjamkan binatang untuk ditunggangi orang Kristen, atau membantu mereka dengan apa pun menyangkut perayaan mereka karena semua itu akan menjadi cara untuk memuliakan penyembahan terhadap berhala dan membantu mereka dalam kekafiran mereka. ${ }^{50}$ Selain itu, Ibn Qayyim menyatakan bahwa kaum Muslim tidak diperbolehkan untuk menghadiri perayaan Kristen karena mereka adalah jenis kebohongan yang jahat. Ia melarang ucapan selamat kepada Kristen pada perayaan agama mereka. ${ }^{51}$

Berdasarkan sudut pandang di atas, sebagian ulama ingin mencegah umat Islam dari ajaran-ajaran sesat yang terkontaminasi dengan bidah melalui kristenisasi karena perayaan Kristen sangat populer di kalangan Muslim. Bahkan, mereka menyarankan Muslim untuk menjauhkan diri dari mereka agar tidak dipengaruhi oleh orang-orang kafir. Namun, penting untuk dicatat dalam perjalanan sejarah bahwa banyak ulama Muslim terdahulu dan Ibn Taymiyyah sendiri juga mengecam perayaan hari kelahiran Muhammad sebagai suatu inovasi bidah yang jelas-jelas berasal dari perayaan natal. ${ }^{52}$

Reaksi lainnya dari dunia Muslim terhadap perayaan Natal yang dapat dikelompokkan

${ }^{48}$ Lihat http://www.geocities.com/Heartland/Fields/2704/article21.htmi dan http:// privatewww.essex.ac.uk/islamic/ilm/nowledge/comparative/xmskufrl.htm.

${ }^{49}$ Memon, lbn Taimiyyah's Struggle, h. 222.

${ }^{50}$ Lihat "Celebrating or Participating in Holidays of the Disbelivers," dalam http://www.islam. com/ilm/onc.htm.

${ }^{51}$ Lihat "Celebrating Christmas," dalam http:// http://www.geocities.com/Heartland/ Fields/2704/article21.htmi.

${ }^{52}$ Memon, lbn Taimiyyah's Struggle, h. 13. 
ke dalam kategori fatwa ini adalah kasus dari fatwa yang dikeluarkan oleh MUI pada 7 Maret $1981 .^{53}$ Indonesia adalah negara dengan populasi terbanyak keempat dengan kirakira 210 juta penduduk, di mana yang populasi Kristen merupakan kurang dari 10 persen dari total. ${ }^{54}$ Populasi mayoritas adalah Islam, namun empat agama lainnya yang telah resmi diakui oleh pemerintah Indonesia sejak pertegahan tahun 1970, yaitu, Protestan, Katolik, Hindu, dan Budha. Merupakan kenyataan bahwa Protestan dan Katolik berasal dari minoritas Kristen yang mempunyai ekonomi dan kekuasaan politik lebih kuat daripada mayoritas Muslim. Ini adalah sebagian konsekuensi dari masa kolonial Belanda. Muslim Indonesia sering memiliki perasaan bahwa mereka berada di minoritas bukan Kristen. ${ }^{55}$

Meskipun mayoritas penduduk Indonesia adalah Muslim dan dinamakan negara Muslim non Arab, Indonesia bukanlah sebuah negara Islam. Masih ada beberapa bagian dari negara di mana Kristen adalah mayoritas. Natal dirayakan dengan hebat di Indonesia. Di beberapa daerah seperti Jawa Tengah, Bali, Medan dan Manado, keunikan dari budaya Indonesia dipadukan dengan perayaan natal tradisional. Perpaduan ini merupakan sebuah simbol penghormatan baik terhadap budaya lokal Indonesia dan Kristen. Di Jakarta, Katedral terbesar dan tertua negara berlokasi berdampingan dengan masjid terbesar, Istiqlal. Ada suatu tradisi yang unik selama musim natal tiba di mana komunitas Muslim membantu dengan memberikan ruang parkir di daerah sekitarnya yang ada di wilayah masjid. Di saat lain, selama hari raya Muslim, orang-orang dari gereja Kristen menawarkan ruang parkir untuk perayaan Muslim. ${ }^{56}$

Muslim dan Kristiani bertukar hadiah dan menghias rumah mereka dengan tumbuhan hijau dan pohon natal. Musim natal dimulai pada awal Desember di beberapa kota. Kotakota yang bisa menandingi kota-kota di Australia, Amerika Serikat, dan Inggris dalam dekorasi mereka. Di Manado, bahkan musim natal dimulai pada bulan Oktober. Orang mulai untuk mempersiapkan pohon natal, pusat perbelanjaan memutar lagu-lagu musim natal dan keluarga dari luar negeri pulang ke rumah untuk merayakan natal bersama. ${ }^{57}$ Musim natal biasanya berakhir pada Minggu ke 3 Januari dengan pesta karnaval di jalanjalan Manado. Hal ini disebut Pigura Carnival yaitu" perayaan penutupan tahun baru". ${ }^{58}$

Dalam merayakan natal di Indonesia, sejumlah besar umat Islam diundang untuk menghadiri perayaan natal. Kehadiran umat Islam sering mengambil beberapa alasan. Pertama, kebudayaan setempat telah tercampur dengan perayaan natal dan sudah menjadi semacam simbol penghormatan untuk keduanya, yaitu budaya lokal Indonesia dan Kristen.

${ }^{53}$ Mudzhar, Fatwa-Fatwa Majelis Ulama Indonesia, h. 117-123.

${ }^{54}$ Lihat "Longest Christmas Season in Indonesia dan Happy Holiday from Christmas.com!," dalam http://christmas.com/pe/1208.

${ }^{55}$ Lihat Beck, Christmas as Identity Marker, h. 106.

${ }^{56}$ Lihat, Kompas, 24 Desember 2001.

${ }^{57}$ Lihat "Happy Holiday!," dalam http://Christmas.com/pe/1214.

${ }^{58}$ Ibid. 
Muslim Indonesia takut dituduh tidak toleran terhadap orang-orang Kristen jika mereka tidak bergabung dalam perayaan tersebut. ${ }^{59} \mathrm{Kedua}$, adanya ikatan keluarga di antara Muslim dan Kristen di beberapa daerah di Indonesia. Ini merupakan kenyataan bahwa umat Islam Indonesia memiliki keluarga dengan para anggotanya termasuk dalam agama yang berbeda. Seperti biasa, anggota keluarga menghadiri hari raya dan perayaan satu sama lain. Alasan ini adalah salah satu yang relevan dalam perjalanan sejarah terutama dalam hal umat Islam di Andalus dan Ceuta. Mungkin tidak terlalu berani untuk menduga bahwa Muslim Andalusia dan Ceuta berpartisipasi dalam perayaan natal dan hari raya Kristen lainnya, bukan karena keaktifan dan keakraban mereka, tetapi pada khususnya, tetapi karena ikatan keluarga yang ada antara Muslim dan Kristen di wilayah ini.

Pada kenyataannya, fatwa yang dikeluarkan oleh MUI pada 7 Maret 1981 harus dipertimbangkan dengan mendasari informasi yang diberikan pada empat paragraf di atas. Otoritas Muslim di Indonesia takut bahwa natal itu menjadi godaan yang besar bagi umat Islam yang menghadiri perayaan natal sejak natal menjadi semakin populer baik dalam keluarga maupun dalam kehidupan umum. Menurut Beck, dalam tulisannya Christmas as Identity Marker, kesalahpahaman nilai teologis dan ritual dari perayaan natal, mungkin secara tidak sengaja melanggar ketentuan hukum Islam atau melupakan ajaran agama Islam. Namun, menurut fatwa yang dikeluarkan pada tanggal 7 Maret 1981, bahaya terbesar bagi umat Islam menghadiri perayaan natal adalah bahwa itu merupakan alasan yang baik untuk mengekspos mereka ke agama Kristen. Selain itu, para ulama berpikir bahwa itu merupakan ancaman langsung dari kristenisasi.

Merujuk pada naskah fatwa tentang Muslim yang menghadiri perayaan natal yang dikeluarkan oleh MUI pada 7 Maret 1981, fatwa dibuat secara terperinci. Dewan fatwa mengutip dua puluh lima ayat al-Qur'an dari sembilan surah. Sebagian besar surah dikutip adalah al-Mâ’idah (surah 5) dan al-Kâfirun (surah 109). Enam ayat dikutip dari dua surah tersebut. Ayat lainnya dikutip dari al-Ikhlâs (empat ayat), Maryam (tiga ayat), al-Baqarah (dua ayat), al-Hujarat, Luqmân, al-Mumtahinah, dan al-Taubah (satu ayat setiapnya). Selain ayat dari al-Qur'an, MUI juga menggunakan satu hadis diriwayatkan oleh Nu'man Ibn Bashir sekaligus merujuk ke teori hukum Islam (usul al-fikih) untuk mendukung argumen teologis yang menarik. ${ }^{60}$ Setelah mengemukakan argumen terperinci mengenai fatwa tersebut kemudian disimpulkan bahwa kehadiran umat Islam pada perayaan natal dilarang secara positif.

\section{Penutup}

Perayaan natal di Indonesia dirayakan secara meriah di mana lagu-lagu natal terdengar di mana-mana dan suasana natal meresapi kehidupan sosial. Otoritas Muslim di Indonesia

\footnotetext{
${ }^{59}$ Mudzhar, Fatwa-fatwa Majelis Ulama Indonesia, h. 101.

${ }^{60}$ Ibid., h. 104.
} 
mengkhawatirkan perayaan natal merupakan godaan yang kuat bagi umat Islam sejak natal menjadi populer dalam keluarga dan dalam kehidupan umum. Bahaya terbesar terletak pada risiko Muslim menjadi tergoda oleh perayaan natal dan kemudian memeluk agama Kristen. Pada dasarnya, orang Kristen dicurigai menggunakan natal sebagai bagian dari strategi konversi mereka. Fatwa yang diterbitkan oleh MUI mengungkapkan hubungan antara ulama dan pemerintah. Di satu sisi, para ulama memiliki tanggung jawab untuk membimbing umat Islam sebagai sebuah komunitas keagamaan. Karena itu, ulama harus banyak memperhatikan pada kepentingan umat. Pemerintah, di sisi lain, berhubungan dengan masyarakat yang berbeda-beda, dengan menganut agama yang berbeda pula. Akibatnya, pemerintah bertindak lebih hati-hati dan teliti dalam berurusan dengan urusan agama, karena itu merupakan daerah sensitif yang dapat menyebabkan stabilitas nasional terganggu.

Kajian terdahulu menjelaskan fakta bahwa ilmuwan Muslim memiliki sudut pandang yang berbeda tentang ajaran Islam yang berkaitan dengan ucapan selamat kepada Kristen saat natal. Di samping itu, mereka juga melihat ajaran Islam yang berkaitan dengan partisipasi Muslim di perayaan non-Muslim pada umumnya berbeda. Pendapat mereka dapat dikategorikan menjadi dua kelompok. Kelompok pertama memandang bahwa ucapan selamat kepada orang Kristen pada saat perayaan natal tidak diperbolehkan. Ulama Muslim, misalnya, Ibn Taimiyyah, Ibn Qayyim, Muhammad Rasyid Ridha, dan Syaikh Muhammad bin Shalih al-Utsaymin melarang Muslim untuk menghadiri dan mengucapkan selamat kepada orang Kristen. Sebaliknya, kelompok lain mengizinkan umat Islam untuk menghadiri dan mengucapkan selamat kepada orang Kristen, misalnya, Shihab dan Qadri mengizinkan Muslim mengucapkan selamat kepada orang Kristen dan untuk merayakan natal selama seorang Muslim melakukannya dengan cara yang bijaksana dan mereka dapat mempertahankan keyakinan/iman mereka dari eliminasi iman. Toleransi agama diperlukan, itulah mengapa tidak benar dan bahkan berdosa jika toleransi agama dikorbankan atas nama agama. Tetapi juga keliru serta berdosa jika kesucian keyakinan agama terkontaminasi oleh aksi atas nama toleransi agama. Karena itu, fatwa yang melarang Muslim mengucapkan selamat kepada Kristen pada perayaan natal mereka dapat dimengerti dalam hal memelihara iman. Selanjutnya, menghadiri perayaan natal diperbolehkan karena dapat membangun rasa saling menghormati antara Islam dan Kristen.

Ada dua contoh dari periode yang berbeda dalam sejarah Islam dari wilayah yang berbeda dari dunia Muslim yang bereaksi terhadap perayaan natal. Pertama, dengan merayakan perayaan kelahiran Nabi Muhammad SAW. Pada abad ketiga belas, Abû al-'Abbas I-'Azafi di Ceuta telah memperkenalkan perayaan maulid untuk mengalihkan perhatian teman seagama Islamnya untuk jauh dari perayaan Kristen. Perayaan maulid, dalam perjalanan sejarah Islam, memiliki dimensi politik yang jelas, misalnya, dalam kasus Abû al-Qasim I- Azafi, putra Abû al-Abbas I-Azafi, yang menyebarkan perayaan maulid sepanjang Maghrib karena perayaan ini memungkinkan penguasa untuk meningkatkan popularitas mereka dan untuk mengamankan diri mereka sendiri dan dukungan dari orang-orang yang berpengaruh dari masyarakat Muslim. Kedua, dengan membuktikan perayaan natal adalah 
bidah bagi umat Islam. Akibatnya, umat Islam menjaga diri mereka sendiri dan memisahkan diri dari perayaan natal. Selain itu, fatwa yang diterbitkan juga merupakan sarana untuk membuat umat Islam menghindari merayakan natal. MUI menerbitkan sebuah fatwa pada tanggal 7 Maret 1981 berkaitan dengan partisipasi umat Islam dalam perayaan natal. Namun, fatwa tersebut berada di bawah tekanan pemerintah Indonesia karena menjadi ancaman berbahaya bagi stabilitas negara yang merugikan kerukunan antar-agama dalam masyarakat Indonesia. Hal ini menunjukkan bahwa pemerintah memiliki pengaruh yang kuat pada pelaksanaan kewenangan ulama. Bagaimanapun, ulama memiliki kewenangan sendiri yang kuat di bidang urusan agama meskipun kadang-kadang untuk kasus tertentu mereka menunjukkan sikap toleran. Selain itu, ulama lebih memilih untuk mempertahankan keputusan mereka pada prinsip-prinsip agama daripada meninggalkan keyakinan mereka meskipun mendapat tekanan kuat dari pihak-pihak tertentu.

\section{Pustaka Acuan}

Al-Utsaymin, Muhammad Ibn Shalihh. "al-Tahni'a bi 'Id al-Krismâsi,” dalam The Council of Supreme Body of Jurists of the Kingdom of Saudi Arabia. Fatâwâ al-Bilâd al- $\underline{\text { Harâm. }}$. Saudi Arabia: t.p., 1999.

Beck, Herman L. "Christmas as Identity Maker, Three Islamic Examples," dalam P. Post dan CH. Caspers (ed.). Christians Feast and Festival: The Dynamic of Western Liturgy and Culture. Leiden: Leuven-Peeters, 2001.

Hamka, Rusydi. Pribadi dan Martabat Buya Prof. Dr. Hamka. Jakarta: Pustaka Panjimas, 1981.

Kaptein, Nico. J. G. Muhammad's Birthday Festival, Early History in the Central Muslim Lands and Development in the Muslim West until the 10 ${ }^{\text {th }} / 16^{\text {th }}$ Century. Leiden: E. J. Brill, 1993.

Landman, Nico. Visies van Moslims in Nederlands op de Christenen en de Kerkedijke Houding Tenover Moslims. Dotoraalscriptie Missiologie Faculteit der Godgeleerdheid, Vrije Universiteit Amsterdam, 1986.

Memon, Muhammad Umar. Ibn Taymiyy's Struggle Against Popular Relegion. Paris: Hague, 1976.

Micheal, Thomas F. A Muslims Theologian's Response to Christianity Ibn Taymiyya's al-Jawab al-Shahih, terj. Thomas F. Micheal. Delmar/New York, 1984.

Mudzhar, Muhammad Atho'. Fatwa-Fatwa Majelis Ulama Indonesia: Sebuah Studi tentang Pemikiran Hukum Islam di Indonesia 1975-1988. Jakarta: Mizan, 1993.

Nurhadi. Muslim's Attendence at Christmas Celebration: A Study on the Fatwa of the Council of Indonesian 'Ulama'. Paper tidak diterbitkan, 1998.

Shadid, W. A. R., dan P. S. Koningsveld (ed.), The Integration of Islam and Hinduism in Western Europe. Netherlands: Kok Pharos, 1991.

Shihab, Muhammad Quraish. Membumikan al-Qur'an. Bandung: Mizan, 1992. 
Shinar, P. "Traditional and Reformist Mawlid Celebrations in the Maghrib," dalam Myryam Rosen-Ayalon (ed.). In Memory of Gaston Wiet. Jerussalem: t.p., 1977.

The Council of Supreme Body of Jurists of the Kingdom of Saudi Arabia. Fatâwâ al-Bilâd

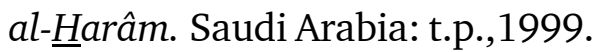

Zarabozo, Jamal al-Din. "Celebrating or Participating in Holidays of the Disbelivers," dalam Majalah al-Jumu'ah, Vol. 9, Issue 2.

"Celebrating Christmas," dalam http:// http://www.geocities.com/Heartland/Fields/ 2704/article21.htmi.

"Celebrating or Participating in Holidays of the Disbelivers," dalam http://www.islam. com/ilm/onc.htm.

"Happy Holiday!," dalam http://Christmas.com/pe/1214.

"Longest Christmas Season in Indonesia dan Happy Holiday from Christmas.com!," dalam http://christmas.com/pe/1208.

Kompas, 24 Desember 2001.

Kompas, 8 Mei 1981.

Pelita, 6 Mei 1981.

Tempo, 1 Agustus 1991.

Tempo, 30 Mei 1981. 